medRxiv preprint doi: https://doi.org/10.1101/2022.02.06.22270558; this version posted February 7, 2022. The copyright holder for this preprint (which was not certified by peer review) is the author/funder, who has granted medRxiv a license to display the preprint in perpetuity.

All rights reserved. No reuse allowed without permission.

\title{
Clinical Severity and mRNA Vaccine Effectiveness for Omicron, Delta, and Alpha SARS-CoV-2 Variants in the United States: A Prospective Observational Study
}

\section{Authors:}

(1) Adam S. Lauring, MD, PhD*

Departments of Internal Medicine and Microbiology and Immunology, University of Michigan, Ann Arbor, Michigan

(2) Mark W. Tenforde, MD, PhD*

CDC COVID-19 Response Team, Atlanta, Georgia

(3) James D. Chappell, MD, PhD*

Department of Pediatrics, Vanderbilt University Medical Center, Nashville, Tennessee

(4) Manjusha Gaglani, MBBS

Baylor Scott and White Health, Texas A\&M University College of Medicine, Temple, Texas

(5) Adit A. Ginde, MD, MPH

Department of Emergency Medicine, University of Colorado School of Medicine, Aurora, Colorado

(6) Tresa McNeal, MD

Baylor Scott and White Health, Texas A\&M University College of Medicine, Temple, Texas

(7) Shekhar Ghamande, MD

Baylor Scott and White Health, Texas A\&M University College of Medicine, Temple, Texas

(8) David J. Douin, MD

Department of Anesthesiology, University of Colorado School of Medicine, Aurora, Colorado

(9) H. Keipp Talbot, MD, MPH

Departments of Medicine and Health Policy, Vanderbilt University Medical Center, Nashville, Tennessee

(10) Jonathan D. Casey, MD, MSci

Department of Medicine, Vanderbilt University Medical Center, Nashville, Tennessee

(11) Nicholas M. Mohr, MD, MS

Department of Emergency Medicine, University of lowa, lowa City, lowa

(12) Anne Zepeski, PharmD

Department of Emergency Medicine, University of lowa, lowa City, lowa

(13) Nathan I. Shapiro, MD, MPH

Department of Emergency Medicine, Beth Israel Deaconess Medical Center, Boston, Massachusetts

(14) Kevin W. Gibbs, MD Department of Medicine, Wake Forest School of Medicine, Winston-Salem, North Carolina

(15) D. Clark Files, MD

Department of Medicine, Wake Forest School of Medicine, Winston-Salem, North Carolina

(16) David N. Hager, MD, PhD

Department of Medicine, Johns Hopkins University School of Medicine, Baltimore, Maryland

(17) Arber Shehu, MD

Department of Medicine, Johns Hopkins University School of Medicine, Baltimore, Maryland

(18) Matthew E. Prekker, MD, MPH

Department of Emergency Medicine and Medicine, Hennepin County Medical Center, Minneapolis, Minnesota

(19) Heidi L. Erickson, MD

Department of Medicine, Hennepin County Medical Center, Minneapolis, Minnesota 
medRxiv preprint doi: https://doi.org/10.1101/2022.02.06.22270558; this version posted February 7, 2022. The copyright holder for this preprint (which was not certified by peer review) is the author/funder, who has granted medRxiv a license to display the preprint in perpetuity.

All rights reserved. No reuse allowed without permission.

(20) Matthew C. Exline, MD, MPH

Department of Medicine, The Ohio State University, Columbus, Ohio

(21) Michelle N. Gong, MD Department of Medicine, Montefiore Health System, Albert Einstein College of Medicine, Bronx, New York

(22) Amira Mohamed, MD Department of Medicine, Montefiore Medical Center, Albert Einstein College of Medicine, Bronx, New York

(23) Nicholas J. Johnson, MD Department of Emergency Medicine and Division of Pulmonary, Critical Care and Sleep Medicine, University of Washington, Seattle, Washington

(24) Vasisht Srinivasan, MD Department of Emergency Medicine, University of Washington, Seattle, Washington

(25) Jay S. Steingrub, MD Department of Medicine, Baystate Medical Center, Springfield, Massachusetts

(26) Ithan D. Peltan, MD, MSc Department of Medicine, Intermountain Medical Center, Murray, Utah and University of Utah, Salt Lake City, Utah

(27) Samuel M. Brown, MD, MS Department of Medicine, Intermountain Medical Center, Murray, Utah and University of Utah, Salt Lake City, Utah

(28) Emily T. Martin, PhD School of Public Health, University of Michigan, Ann Arbor, Michigan

(29) Arnold S. Monto, MD School of Public Health, University of Michigan, Ann Arbor, Michigan

(30) Akram Khan, MD Department of Medicine, Oregon Health and Sciences University, Portland, Oregon

(31) Catherine L. Hough, MD Department of Medicine, Oregon Health and Sciences University, Portland, Oregon

(32) Laurence W. Busse, MD Department of Medicine, Emory University, Atlanta, Georgia

(33) Caitlin C. ten Lohuis, ACNP-BC Emory Critical Care Center, Emory Healthcare, Atlanta, Georgia

(34) Abhijit Duggal, MD Department of Medicine, Cleveland Clinic, Cleveland, Ohio

(35) Jennifer G. Wilson, MD Department of Emergency Medicine, Stanford University School of Medicine, Stanford, California

(36) Alexandra June Gordon, MD Department of Emergency Medicine, Stanford University School of Medicine, Stanford, California

(37) Nida Qadir, MD Department of Medicine, University of California-Los Angeles, Los Angeles, California

(38) Steven Y. Chang, MD, PhD Department of Medicine, University of California-Los Angeles, Los Angeles, California

(39) Christopher Mallow, MD, MHS Department of Medicine, University of Miami, Miami, Florida

(40) Carolina Rivas 
medRxiv preprint doi: https://doi.org/10.1101/2022.02.06.22270558; this version posted February 7, 2022. The copyright holder for this preprint (which was not certified by peer review) is the author/funder, who has granted medRxiv a license to display the preprint in perpetuity.

All rights reserved. No reuse allowed without permission.

Department of Medicine, University of Miami, Miami, Florida

(41) Hilary M. Babcock, MD, MPH Department of Medicine, Washington University, St. Louis, Missouri

(42) Jennie H. Kwon, DO, MS Department of Medicine, Washington University, St. Louis, Missouri

(43) Natasha Halasa, MD, MPH Department of Pediatrics, Vanderbilt University Medical Center, Nashville, Tennessee

(44) Carlos G. Grijalva, MD, MPH Department of Health Policy, Vanderbilt University Medical Center, Nashville, Tennessee

(45) Todd W. Rice, MD, MSci Department of Medicine, Vanderbilt University Medical Center, Nashville, Tennessee

(46) William B. Stubblefield, MD, MPH Department of Emergency Medicine, Vanderbilt University Medical Center, Nashville, Tennessee

(47) Adrienne Baughman Department of Emergency Medicine, Vanderbilt University Medical Center, Nashville, Tennessee

(48) Kelsey N. Womack, PhD Vanderbilt Institute for Clinical and Translational Research, Vanderbilt University Medical Center, Nashville, Tennessee

(49) Jillian P. Rhoads, PhD Vanderbilt Institute for Clinical and Translational Research, Vanderbilt University Medical Center, Nashville, Tennessee

(50) Christopher J. Lindsell, PhD Department of Biostatistics, Vanderbilt University Medical Center, Nashville, Tennessee

(51) Kimberly W. Hart, MA Department of Biostatistics, Vanderbilt University Medical Center, Nashville, Tennessee

(52) Yuwei Zhu, MD, MS Department of Biostatistics, Vanderbilt University Medical Center, Nashville, Tennessee

(53) Katherine Adams, MPH CDC COVID-19 Response Team, Atlanta, Georgia

(54) Stephanie J. Schrag, Dphil CDC COVID-19 Response Team, Atlanta, Georgia

(55) Samantha M. Olson, MPH CDC COVID-19 Response Team, Atlanta, Georgia

(56) Miwako Kobayashi, MD CDC COVID-19 Response Team, Atlanta, Georgia

(57) Jennifer R. Verani, MD CDC COVID-19 Response Team, Atlanta, Georgia

(58) Manish M. Patel, MD CDC COVID-19 Response Team, Atlanta, Georgia

(59) Wesley H. Self, MD, MPH Department of Emergency Medicine and Vanderbilt Institute for Clinical and Translational Research, Vanderbilt University Medical Center, Nashville, Tennessee

For the Influenza and Other Viruses in the Acutely III (IVY) Network**

* Dr. Lauring, Dr. Tenforde, and Dr. Chappell contributed equally to this work as lead authors.

**A full list of investigators and collaborators in the Influenza and other Viruses in the Acutely III (IVY) Network is available in the Supplementary Appendix. 
medRxiv preprint doi: https://doi.org/10.1101/2022.02.06.22270558; this version posted February 7, 2022. The copyright holder for this preprint (which was not certified by peer review) is the author/funder, who has granted medRxiv a license to display the preprint in perpetuity.

All rights reserved. No reuse allowed without permission.

145 Corresponding Author:

146 Wesley H. Self, MD, MPH; Vanderbilt University Medical Center; email: wesley.self@vumc.org; mail:

$147131321^{\text {st }}$ Avenue South, 312 Oxford House, Nashville TN 37232, USA. ORCID: 0000-0002-9300-3045.

148

149

Disclaimer:

150 The findings and conclusions in this report are those of the authors and do not necessarily represent the

151 views of the Centers for Disease Control and Prevention/the Agency for Toxic Substances and Disease

152 Registry.

153

154 Key Words:

155 COVID-19; SARS-CoV-2; vaccine effectiveness; attenuation; mRNA vaccines; delta variant; omicron

156 variant

157

158 Word Counts:

159 Abstract: 390

160 Main Text: 4385 
medRxiv preprint doi: https://doi.org/10.1101/2022.02.06.22270558; this version posted February 7, 2022. The copyright holder for this preprint (which was not certified by peer review) is the author/funder, who has granted medRxiv a license to display the preprint in perpetuity.

All rights reserved. No reuse allowed without permission.

161

162

163

164

165

166

167

168

169

170

171

172

173

174

175

176

177

178

179

180

181

182

\section{ABSTRACT}

Objectives: To characterize the clinical severity of COVID-19 caused by Omicron, Delta, and Alpha SARSCoV-2 variants among hospitalized adults and to compare the effectiveness of mRNA COVID-19 vaccines to prevent hospitalizations caused by each variant.

Design: A case-control study of 11,690 hospitalized adults.

Setting: Twenty-one hospitals across the United States.

Participants: This study included 5728 cases hospitalized with COVID-19 and 5962 controls hospitalized without COVID-19. Cases were classified into SARS-CoV-2 variant groups based on viral whole genome sequencing, and if sequencing did not reveal a lineage, by the predominant circulating variant at the time of hospital admission: Alpha (March 11 to July 3, 2021), Delta (July 4 to December 25, 2021), and Omicron (December 26, 2021 to January 14, 2022).

Main Outcome Measures: Vaccine effectiveness was calculated using a test-negative design for COVID19 mRNA vaccines to prevent COVID-19 hospitalizations by each variant (Alpha, Delta, Omicron). Among hospitalized patients with COVID-19, disease severity on the WHO Clinical Progression Ordinal Scale was compared among variants using proportional odds regression.

Results: Vaccine effectiveness of the mRNA vaccines to prevent COVID-19-associated hospitalizations included: $85 \%$ (95\% Cl: 82 to $88 \%$ ) for 2 vaccine doses against Alpha; $85 \%$ (95\% Cl: 83 to $87 \%$ ) for 2 doses against Delta; 94\% (95\% Cl: 92 to 95\%) for 3 doses against Delta; 65\% (95\% Cl: 51 to 75\%) for 2 doses against Omicron; and 86\% (95\% Cl: 77 to 91\%) for 3 doses against Omicron. Among hospitalized unvaccinated COVID-19 patients, severity on the WHO Clinical Progression Scale was higher for Delta than Alpha (adjusted proportional odds ratio [aPOR] 1.28, 95\% Cl: 1.11 to 1.46), and lower for Omicron than Delta (aPOR 0.61, 95\% Cl: 0.49 to 0.77 ). Compared to unvaccinated cases, severity was lower for 
medRxiv preprint doi: https://doi.org/10.1101/2022.02.06.22270558; this version posted February 7, 2022. The copyright holder for this preprint (which was not certified by peer review) is the author/funder, who has granted medRxiv a license to display the preprint in perpetuity.

All rights reserved. No reuse allowed without permission.

183 vaccinated cases for each variant, including Alpha (aPOR $0.33,95 \% \mathrm{Cl}: 0.23$ to 0.49 ), Delta (aPOR 0.44 ,

$18495 \% \mathrm{Cl}: 0.37$ to 0.51 ), and Omicron (aPOR 0.61, 95\% Cl: 0.44 to 0.85 ).

185 Conclusions: mRNA vaccines were highly effective in preventing COVID-19-associated hospitalizations

186 from Alpha, Delta, and Omicron variants, but three vaccine doses were required to achieve protection

187 against Omicron similar to the protection that two doses provided against Delta and Alpha. Among

188 adults hospitalized with COVID-19, Omicron caused less severe disease than Delta, but still resulted in

189 substantial morbidity and mortality. Vaccinated patients hospitalized with COVID-19 had significantly

190 lower disease severity than unvaccinated patients for all the variants. 
medRxiv preprint doi: https://doi.org/10.1101/2022.02.06.22270558; this version posted February 7, 2022. The copyright holder for this preprint (which was not certified by peer review) is the author/funder, who has granted medRxiv a license to display the preprint in perpetuity.

All rights reserved. No reuse allowed without permission.

\section{INTRODUCTION}

192 The coronavirus disease 2019 (COVID-19) pandemic has been defined by both the distribution of highly

193 effective vaccines and the serial emergence of new severe acute respiratory syndrome coronavirus-2

194 (SARS-CoV-2) genetic variants [1]. Variants of concern are new genetic versions of the virus with increased transmissibility, a change in virulence or disease presentation, or a decrease in effectiveness

SARS-CoV-2 variants of concern: Alpha (B.1.1.7 and descendant lineages), Beta (B.1.351), Gamma (P.1),

Delta (B.1.617.2 and AY lineages), and Omicron (B.1.1.529 and BA lineages).

First identified in Spring 2021, the highly contagious Delta variant rapidly replaced other SARS-

CoV-2 variants and achieved global dominance by Summer 2021 [3]. Early studies suggested potential for increased risk of hospitalization for Delta-infected individuals compared to prior variants [4-6]. The dominant variant in much of Europe and North America by late-December 2021 [7]. The overall risk of hospitalization among those infected with the Omicron variant appears to be lower than those infected and risk for progression to critical illness remain incompletely understood for this variant. against them are essential to guide vaccination policies and development of new vaccines. Early studies

209 suggested reduced vaccine effectiveness against infection and hospitalization for Omicron compared to

210 earlier variants [9-11]. In most cases, estimates of vaccine effectiveness against the Omicron variant

211 were based on cases that occurred during time periods in which the Omicron variant exceeded $50 \%$ in

212 genomic surveillance. While efficient, these approaches have the potential for variant misclassification 213 and inaccurate vaccine effectiveness estimates. Furthermore, little is known about the effectiveness of 
medRxiv preprint doi: https://doi.org/10.1101/2022.02.06.22270558; this version posted February 7, 2022. The copyright holder for this preprint (which was not certified by peer review) is the author/funder, who has granted medRxiv a license to display the preprint in perpetuity.

All rights reserved. No reuse allowed without permission.

214 vaccines for the prevention of the most severe manifestations of COVID-19, including respiratory failure

215 and death, for patients with Omicron infection.

Using observational study designs, the Influenza and Other Viruses in the Acutely III (IVY)

217 Network in collaboration with the United States Centers for Disease Control and Prevention (CDC) is

218 studying the effectiveness of COVID-19 vaccines against severe disease (Table S1) [12-15]. Here, we

219 compare the clinical severity of COVID-19 caused by the SARS-CoV-2 Alpha, Delta and Omicron variants

220 among hospitalized adults in the United States and the effectiveness of mRNA COVID-19 vaccines

221 against each of these variants.

222

\section{METHODS}

\section{Design and Setting}

225 We conducted a prospective observational study at 21 hospitals in the United States, with enrollment of 226 adults hospitalized with laboratory-confirmed COVID-19 and concurrent controls without COVID-19. A

227 test-negative design was utilized to assess vaccine effectiveness [16]. This program was conducted by

228 the IVY Network, which is a group consisting of geographically dispersed academic medical centers in

229 the United States, coordinated from Vanderbilt University Medical Center, and funded by CDC (Table

230 S1). Participants enrolled in the IVY program with hospital admission dates between March 11, 2021,

231 and January 14, 2022 were included in this analysis. This program was approved as a public health

232 surveillance activity with waiver of informed consent by CDC and all participating sites.

234 vaccine effectiveness of the COVID-19 mRNA vaccines to prevent hospitalizations due to each variant;

235 (2) disease severity among unvaccinated and vaccinated patients hospitalized with each variant; and (3) 
medRxiv preprint doi: https://doi.org/10.1101/2022.02.06.22270558; this version posted February 7, 2022. The copyright holder for this preprint (which was not certified by peer review) is the author/funder, who has granted medRxiv a license to display the preprint in perpetuity.

All rights reserved. No reuse allowed without permission.

vaccine effectiveness of the COVID-19 mRNA vaccines to prevent disease progression to invasive mechanical ventilation or death after hospitalization with each variant.

\section{Participants}

Sites prospectively screened hospitalized adults $\geq 18$ years old for potential eligibility through daily review of hospital admission logs and electronic medical records. COVID-19 cases included those hospitalized with a clinical syndrome consistent with acute COVID-19 ( $\geq 1$ of the following: fever; cough; shortness of breath; loss of taste; loss of smell; use of respiratory support for the acute illness; or new pulmonary findings on chest imaging consistent with pneumonia) and a positive molecular or antigen test for SARS-CoV-2 within 10 days of symptom onset. As described below, COVID-19 case patients were subclassified based on SARS-CoV-2 variant. Additionally, two control groups were enrolled: 1) "testnegative" controls were adults hospitalized with signs or symptoms consistent with acute COVID-19 who tested negative for SARS-CoV-2; and 2) "syndrome-negative" controls were adults hospitalized without signs or symptoms consistent with acute COVID-19 and who tested negative for SARS-CoV-2 [17]. Controls were selected from lists of eligible participants hospitalized within 2 weeks of enrollment of COVID-19 cases. Sites attempted to capture all COVID-19 cases admitted to the hospital during the surveillance period and targeted a case: control ratio of approximately 1:1. Cases and controls were not individually matched. Respiratory samples from participants were tested for SARS-CoV-2 both locally in clinical laboratories and centrally at a research laboratory (see Laboratory Analysis section). Cases tested positive for SARS-CoV-2 at a local laboratory, the central laboratory, or both, while controls tested negative for SARS-CoV-2 by all testing. Additional details about eligibility criteria and enrollment practices are described in Supplementary Appendix B [13,14]. 
medRxiv preprint doi: https://doi.org/10.1101/2022.02.06.22270558; this version posted February 7, 2022. The copyright holder for this preprint (which was not certified by peer review) is the author/funder, who has granted medRxiv a license to display the preprint in perpetuity.

All rights reserved. No reuse allowed without permission.

\section{Data Collection}

260 Trained personnel collected data on demographics, medical conditions, COVID-19 vaccination, and

261 hospital course through participant (or proxy) interviews and standardized medical record review.

262 Details of COVID-19 vaccination, including dates and location of vaccination, vaccine product, and lot

263 number, were collected through a systematic process that included participant (or proxy) interview and

264 source verification by vaccination card, hospital records, state vaccine registries, and vaccine records

265 requested from clinics and pharmacies $[13,14]$.

\section{Vaccination Status}

268 Vaccine doses were classified as administered if source documentation of the dose was identified or if

269 the participant/proxy reported a vaccine dose with a complete and plausible date and location. This

270 analysis focused on COVID-19 mRNA vaccines authorized or approved for use in the United States,

271 including BNT162b2 (Pfizer-BioNTech) and mRNA-1273 (Moderna). Participants were classified based on

272 the number of mRNA vaccine doses received before illness onset: 0 doses (unvaccinated); 1 dose $\geq 14$

273 days before illness (partially vaccinated); 2 doses $\geq 14$ days before illness (fully vaccinated); or 3 doses $\geq 7$

274 days before illness (boosted if immunocompetent, or with primary 3-dose series completed if

275 immunocompromised). In the primary analysis, vaccine effectiveness was calculated for 2 vaccine doses

276 for participants enrolled throughout the surveillance period and for 3 vaccine doses for participants

277 enrolled after third doses were authorized in the United States $[18,19]$. In a secondary analysis, vaccine

278 effectiveness was calculated for partial vaccination. Participants were excluded from this analysis if they

279 received a COVID-19 vaccine other than an mRNA vaccine (e.g., the Ad26.COV2 vaccine from Janssen),

280 more than 3 vaccine doses, or a third vaccine dose before they were authorized in the United States

281 [18-20]. 
medRxiv preprint doi: https://doi.org/10.1101/2022.02.06.22270558; this version posted February 7, 2022. The copyright holder for this preprint (which was not certified by peer review) is the author/funder, who has granted medRxiv a license to display the preprint in perpetuity.

All rights reserved. No reuse allowed without permission.

\section{Laboratory Analysis}

283 death or invasive mechanical ventilation (levels 4-6).

\section{COVID-19 disease severity}

Upper respiratory specimens (nasal swabs or saliva) were collected from participants, frozen, and shipped to Vanderbilt University Medical Center (Nashville, Tennessee), where they underwent reversetranscription quantitative polymerase chain reaction (RT-qPCR) for detection of two SARS-CoV-2 nucleocapsid gene targets (N1 and N2) [21]. Respiratory specimens positive for SARS-CoV-2 were shipped to the University of Michigan (Ann Arbor, Michigan) for viral whole-genome sequencing using the ARTIC Network protocol on an Oxford Nanopore Technologies GridION instrument [22]. SARS-CoV-2 lineages were assigned using Pangolin [23]. The WHO variant assignment was as follows: Alpha (B.1.1.7), Beta (B.1.351), Gamma (P.1), Delta (B.1.617.2 and AY lineages), Omicron (B.1.1.529 or BA lineages).

We classified COVID-19 disease severity based on the highest severity state reached during the index COVID-19 hospital admission using a modified version of the WHO COVID-19 Clinical Progression Scale (Table S2) $[13,24]$. In this analysis of hospitalized patients, the scale levels included: hospitalized without supplemental oxygen (level 4), hospitalized with standard supplemental oxygen (level 5), hospitalized with high flow nasal cannula or non-invasive ventilation (level 6), hospitalized with invasive mechanical ventilation (level 7), hospitalized with mechanical ventilation and additional organ support (e.g., ECMO, vasopressors; level 8), and death (level 9). In addition to evaluating the full scale (levels 4-9) as an ordinal outcome, we also dichotomized the scale at level 7 to facilitate comparison between patients who experienced death or invasive mechanical ventilation (levels 7-9) vs those who did not experience 
medRxiv preprint doi: https://doi.org/10.1101/2022.02.06.22270558; this version posted February 7, 2022. The copyright holder for this preprint (which was not certified by peer review) is the author/funder, who has granted medRxiv a license to display the preprint in perpetuity.

All rights reserved. No reuse allowed without permission.

\section{Statistical Analysis}

305

306

307

308

309

310

311

312

313

314

315

316

317

318

319

320

321

322

323

324

325

326

327

COVID-19 cases were classified into Alpha, Delta, and Omicron categories using sequencing information

for cases with lineages identified and by the predominant circulating variant at the time of hospital

admission for those without a lineage identified. Periods of predominant circulation for Alpha, Delta and Omicron were defined based on time windows when each variant was identified in $>50 \%$ of cases successfully sequenced in the study -Alpha period: March 11 - July 3, 2021; Delta period: July 4 December 25, 2021; and Omicron period: December 26, 2021 - January 14, 2022. For analyses evaluating vaccine effectiveness to prevent hospitalization, evaluating cases and controls enrolled during the same time period was important to maintain accuracy of vaccine effectiveness estimates. For analyses evaluating vaccine effectiveness against hospitalization, cases and controls in each period (Alpha, Delta, and Omicron) were compared; cases were excluded from these analyses if they had a lineage identified by sequencing that was discordant with the period (for example, a Delta lineage identified in the Omicron period). For severity analyses, only cases were analyzed and maintaining a temporal relationship with a control group was not necessary; therefore, all cases with sequencingconfirmed Alpha, Delta, or Omicron lineage were analyzed regardless of admission date; in these analyses, variant group was classified by sequencing confirmation of Alpha, Delta or Omicron lineage, and then for other cases, by period.

Vaccine effectiveness of COVID-19 mRNA vaccines (BNT162b2 or mRNA-1273) to prevent hospitalization for COVID-19 was calculated using a test-negative design, in which the odds of antecedent vaccination were compared between cases and controls. Participants in the test-negative and syndrome-negative control groups were pooled based on analyses demonstrating highly similar vaccine coverage in the two control groups and nearly identical vaccine effectiveness estimates when either control group was used individually [14]. A multivariable unconditional logistic regression model was constructed with case-control status as the dependent variable, vaccination status (vaccinated vs. 
medRxiv preprint doi: https://doi.org/10.1101/2022.02.06.22270558; this version posted February 7, 2022. The copyright holder for this preprint (which was not certified by peer review) is the author/funder, who has granted medRxiv a license to display the preprint in perpetuity.

All rights reserved. No reuse allowed without permission.

unvaccinated) as the primary independent variable and the following covariables selected a priori as potential confounders: calendar date of admission in biweekly intervals, US Department of Health and Human Services region (10 regions), age, sex, and self-reported race and Hispanic ethnicity. Post-hoc, the following variables were considered for potential inclusion as covariates but none of them changed the adjusted odds ratio (aOR) by more than $5 \%$ and were not included in the final analysis: number of comorbidities, smoking status, living in a long-term care facility before hospital admission and working in a healthcare setting. Vaccine effectiveness to prevent COVID-19 hospitalization [VE(hospitalization)] was calculated with the adjusted odds ratio (aOR) from this model as: VE(hospitalization) $=(1-\mathrm{aOR}) \times 100$. Using this method, vaccine effectiveness against COVID-19 hospitalization as calculated separately for the Alpha, Delta, and Omicron. Vaccine effectiveness for two vaccine doses was calculated for each period, and for three vaccine doses for the Delta and Omicron periods. Within each period, vaccine effectiveness was also calculated for subgroups defined by: immunocompromised status [14]; age group (18-64 years; $\geq 65$ years); burden of chronic medical conditions $(0 ; \geq 1$ medical conditions); vaccine product (BNT162b2; mRNA-1273); and for two vaccine doses recipients, the time between the second vaccine dose and symptom onset (14-150 days; $>150$ days). This threshold of 150 days was selected based on the recommendation for a third (booster) dose of mRNA vaccine after 5 months for immunocompetent adults [23]. Results for subgroup analyses that had $>150$ cases and controls were reported.

COVID-19 severity by variant and by vaccination status was displayed by plotting the highest severity level on the modified WHO Clinical Progression Scale attained for each case. COVID-19 severity was compared among unvaccinated cases by variant (Alpha, Delta, Omicron) and between unvaccinated and vaccinated cases within each group. In these analyses of severity, patients vaccinated with either 2 or 3 doses of an mRNA vaccine were considered fully vaccinated. These calculations were performed using a multivariable proportional odds regression model with WHO ordinal scale as the dependent 
medRxiv preprint doi: https://doi.org/10.1101/2022.02.06.22270558; this version posted February 7, 2022. The copyright holder for this preprint (which was not certified by peer review) is the author/funder, who has granted medRxiv a license to display the preprint in perpetuity.

All rights reserved. No reuse allowed without permission.

variable (levels 4-9), variant group (Alpha, Delta, Omicron) or vaccination status (unvaccinated,

353 vaccinated) as the primary independent variable and the following covariables: age, sex, race and

354 Hispanic ethnicity, and number of underlying medical conditions $(0,1,2,3$, or $\geq 4$ classes of chronic

355 conditions). An adjusted proportional odds ratio (aPOR) $>1.0$ from these models indicated more severe

356 disease for the later variant than a comparator earlier variant, for example Delta compared with Alpha,

357 and Omicron compared with Delta.

Next, the vaccine effectiveness was calculated for mRNA vaccines to prevent disease

progression to invasive mechanical ventilation or death among adults hospitalized with COVID-19. A

multivariable logistic regression model was constructed with the composite of invasive mechanical

361 ventilation or death as the dependent variable, vaccination status (vaccinated with 2 or 3 doses vs

unvaccinated) as the primary independent variable and the same covariables as included in the severity

proportional odds model. Vaccine effectiveness to prevent in-hospital disease progression was

calculated as: $\mathrm{VE}($ progression $)=(1-\mathrm{aOR}) \times 100$. Using this method, vaccine effectiveness against

disease progression was calculated separately for the Alpha, Delta, and Omicron groups.

367 not include the null ( $O R=1.0)$ or two-sided $p$-values were $<0.05$. Missing values were not imputed;

368 results were presented with denominators to indicate sample size in each analysis and models included

369 participants with complete data for all variables in the model. Statistical analyses were performed with

370 Stata Version 16 (College Station, TX) and SAS 9.4 (Cary, NC). 
medRxiv preprint doi: https://doi.org/10.1101/2022.02.06.22270558; this version posted February 7, 2022. The copyright holder for this preprint (which was not certified by peer review) is the author/funder, who has granted medRxiv a license to display the preprint in perpetuity.

All rights reserved. No reuse allowed without permission.

Between March 11, 2021 and January 14, 2022, 14,128 patients were enrolled across 21 hospitals; 2,438 patients were excluded from the primary analyses, most commonly for receiving $>1$ mRNA vaccine dose but not classifying into the two-dose or three-dose vaccine recipient categories ( $n=933$ ) or for receiving a non-mRNA vaccine ( $\mathrm{n}=682$ ) (Figure S1). The population for analysis included 11,690 patients, including 5,728 COVID-19 cases and 5,962 controls.

SARS-CoV-2 sequencing results were obtained for 2,599/5,728 (45\%) cases in the analytical population. Among cases with sequencing completed, during the Alpha period 242/421 (57\%) cases had Alpha identified by sequencing, during the Delta period 1,867/1,930 (97\%) cases had Delta identified by sequencing, and during the Omicron period 190/248 (77\%) cases had Omicron identified by sequencing (Figure 1; Table S3).

\section{Vaccine Effectiveness to Prevent COVID-19 Hospitalizations}

After excluding 146/5,728 (3\%) cases from the vaccine effectiveness against hospitalization analysis who had sequence-confirmed lineage discordant from the variant-predominant period (e.g., cases with sequencing-confirmed Delta variant during the Alpha or Omicron period), 5,582 cases and 5,962 controls were included in this part of the analysis. Cases included 1,072 from the Alpha period, 3,951 from the Delta period, and 559 from the Omicron period. Compared to cases in the Alpha and Delta period, cases in the Omicron group tended to be older, have more underlying medical conditions, and more likely to have $\geq 1$ prior hospitalization in the past year (Table 1, Table S4). Consistent with increasing vaccine coverage in the United States population over time, a greater proportion of cases were vaccinated ( 2 or 3 doses of an mRNA vaccine) during the Omicron period (291/559, 52\%) than the Alpha (119/1072, 11\%) and Delta (1080/3951, 27\%) periods. 
medRxiv preprint doi: https://doi.org/10.1101/2022.02.06.22270558; this version posted February 7, 2022. The copyright holder for this preprint (which was not certified by peer review) is the author/funder, who has granted medRxiv a license to display the preprint in perpetuity.

All rights reserved. No reuse allowed without permission.

Vaccine effectiveness for two doses of mRNA vaccine to prevent COVID-19 hospitalization was

$85 \%$ (95\% Cl: 82 to $88 \%$ ) in the Alpha period, $85 \%$ (95\% Cl: 83 to $87 \%$ ) in the Delta period, and 65\% (95\%

the Omicron period was $86 \%$ (95\% $\mathrm{Cl}: 77$ to $91 \%$ ), which was similar to the effectiveness of two doses

during the Alpha and Delta periods. Within the Delta period, vaccine effectiveness for two vaccine doses

407 BNT162b2 vaccine than the mRNA-1273 vaccine. Vaccine effectiveness results for partial vaccination

408 (either 1 dose of an mRNA vaccine or 2 doses with the second dose received $<14$ days before illness onset) are described in Supplementary Appendix C.

\section{COVID-19 Disease Severity}

412 The severity analysis included data collected through January 31,2022 . Of 5,728 case patients in the

413 study, 5,413 (95\%) had complete clinical outcomes data and were included in the severity analysis,

414 including 1,060 in the Alpha group, 3,788 in the Delta group, and 565 in the Omicron group. Overall,

415 including both vaccinated and unvaccinated patients, 582/5,413 (11\%) COVID-19 patients died within 28

416 days during the index hospitalization, including $81 / 1,060(8 \%)$ in the Alpha group, $461 / 3,788(12 \%)$ in

417 the Delta group, and 40/565 (7\%) in the Omicron group. 
medRxiv preprint doi: https://doi.org/10.1101/2022.02.06.22270558; this version posted February 7, 2022. The copyright holder for this preprint (which was not certified by peer review) is the author/funder, who has granted medRxiv a license to display the preprint in perpetuity.

All rights reserved. No reuse allowed without permission.

Among unvaccinated cases, COVID-19 severity on the WHO Clinical Progression Scale was

419 highest for the Delta group (Delta vs Alpha aPOR 1.28, 95\% Cl: 1.11 to 1.46) and lowest for the Omicron

420 group (Omicron vs Alpha aPOR 0.79, 95\% Cl: 0.62 to 1.01; Omicron vs Delta aPOR 0.61, 95\% Cl: 0.49 to

421 0.77) (Figure 3). Among unvaccinated cases, in-hospital death occurred in 76/944 (8\%) in the Alpha

422 group, 323/2,743 (12\%) in the Delta group, and 25/272 (9\%) in the Omicron group (Table 2). COVID-19

423 severity on the WHO Clinical Progression Scale was substantially lower for vaccinated cases than

424 unvaccinated cases in each variant group, including Alpha (aPOR: 0.33; 95\% Cl: 0.23-0.49), Delta (aPOR

$4250.44 ; 95 \% \mathrm{Cl}: 0.37$ to 0.51 ), and Omicron (aPOR: $0.61 ; 95 \% \mathrm{Cl}: 0.44$ to 0.85 ).

Across all variants, vaccinated COVID-19 patients who died tended to be old and had multiple

427 medical conditions or immunocompromising conditions. Compared with the 424 unvaccinated COVID-19

428 patients who died, 158 vaccinated patients who died were older (median 72 vs 61 years; $p<0.001$ ), more

429 likely to be immunocompromised (41\% versus $13 \%$; $p<0.001$ ), had more categories of chronic medical

430 conditions (median 3 versus 2; $\mathrm{p}<0.001$ ), and had more prescribed medications prior to hospital

431 admission (median 10 versus 5; $p<0.001$ ).

\section{Vaccine Effectiveness to Prevent COVID-19 Disease Progression after Hospitalization}

434 Among patients hospitalized with COVID-19, vaccine effectiveness of mRNA vaccination (2 or 3 doses) to 435 prevent progression to invasive mechanical ventilation or death was $76 \%$ (95\% Cl: 53 to $88 \%$ ) for Alpha, $43644 \%$ (95\% Cl: 32 to 54\%) for Delta, and $46 \%$ (95\% Cl: 12 to 67\%) for Omicron. Vaccine effectiveness to 437 prevent disease progression was observed for immunocompetent patients for all three variants, but not 438 observed for immunocompromised patients for Delta or Omicron (Figure 4). 
medRxiv preprint doi: https://doi.org/10.1101/2022.02.06.22270558; this version posted February 7, 2022. The copyright holder for this preprint (which was not certified by peer review) is the author/funder, who has granted medRxiv a license to display the preprint in perpetuity.

All rights reserved. No reuse allowed without permission.

DISCUSSION

\section{Principal Findings}

442 The predominant circulating SARS-CoV-2 variant in the United States changed from Alpha to Delta in July

4432021 and then to Omicron in December 2021. Understanding the disease severity caused by each

444 variant and the effectiveness of available vaccines against them is essential for guiding vaccination

445 policies and directing future vaccine development. The mRNA COVID-19 vaccines that were authorized

446 for use in the United States in 2020 (BNT162b2 and mRNA-1273) were highly effective at preventing

447 hospitalizations for all three variants during the subsequent year. However, three doses of an mRNA

448 vaccine were necessary to achieve similar effectiveness against Omicron in the winter of 2021-2022 as

449 two doses achieved for Alpha and Delta variants earlier in the year. Furthermore, while COVID-19

450 hospitalizations did occur among vaccinated patients, vaccination was associated with reduced risk of

451 progression to invasive mechanical ventilation or death for all three variants.

Among unvaccinated hospitalized adults with COVID-19, Delta variant caused the most severe

453 disease, followed by Alpha, and then Omicron. Among hospitalized unvaccinated patients, COVID-19

454 caused by Omicron was about 79\% as severe as Alpha and 61\% as severe as Delta. However, the

455 Omicron variant did cause a substantial amount of critical illness and death, with $15 \%$ of all patients

456 hospitalized with Omicron (vaccinated and unvaccinated) progressing to invasive mechanical ventilation

457 and 7\% dying in the hospital.

459 Strengths and Limitations

460 This work has several strengths. The vaccine effectiveness analyses applied a test-negative design to a

461 large, hospitalized population of patients with symptomatic, laboratory-confirmed COVID-19 and 
medRxiv preprint doi: https://doi.org/10.1101/2022.02.06.22270558; this version posted February 7, 2022. The copyright holder for this preprint (which was not certified by peer review) is the author/funder, who has granted medRxiv a license to display the preprint in perpetuity.

All rights reserved. No reuse allowed without permission.

462

463

464

465

466

467

468

469

470

471

472

473

474

475

476

477

478

479

480

481

482

483

484

485

concurrent controls, which enabled control for healthcare seeking behavior, robust subgroup analyses, and evaluation of outcomes beyond hospital admission, including level of respiratory support and mortality. Ascertainment of vaccination status was robust, with trained personnel conducting patient interviews and searching multiple sources of vaccination records on a patient-by-patient basis.

Respiratory samples collected in the study underwent centralized RT-PCR testing and viral whole genome sequencing, which enabled precise characterization of time periods dominated by different variants.

The study also had limitations. First, use of hospitalized controls might lead to biased estimates if control patients had different characteristics than people in the general community; however, vaccine coverage in the control population within this study tracked closely with that in the adult population in the United States [25], which lessens this potential concern. Second, this study only evaluated hospitalized patients and thus does not inform vaccine effectiveness against mild COVID-19 or differences in disease severity among SARS-CoV-2 variants in the outpatient setting. Third, the study only evaluated mRNA vaccines and did not assess other types of COVID-19 vaccines. Fourth, the analyses of in-hospital severity did not account for potential differences in clinical management during the Alpha, Delta, and Omicron periods that may have impacted outcomes. Fifth, while the test negative design is the preferred method for evaluating vaccine effectiveness with observational data [16], it has known potential limitations, including collider bias [26,27]; the risk of collider bias was minimized in the current study by evaluating only severely ill patients [16]. Sixth, sequencing did not identify a variant for some cases, typically those with low viral loads in the respiratory sample that underwent testing. Variant classification for cases without a sequencing-confirmed variant was based on the predominant circulating variant at the time; variant misclassification was possible for these cases. 
medRxiv preprint doi: https://doi.org/10.1101/2022.02.06.22270558; this version posted February 7, 2022. The copyright holder for this preprint (which was not certified by peer review) is the author/funder, who has granted medRxiv a license to display the preprint in perpetuity.

All rights reserved. No reuse allowed without permission.

486

487

488

489

490

491

492

493

494

495

496

497

498

499

500

501

502

503

504

505

Earlier studies from England [5] and Scotland [4] found an increased risk of hospital admission for Delta variant compared to Alpha variant. More recent studies have suggested that persons diagnosed with Omicron variant COVID-19 are less likely than those with Delta to be hospitalized [8]. This study adds robust measurements of disease severity after hospital admission and demonstrates Delta variant caused more severe disease than Alpha and Omicron variants, driven largely by higher rates of advanced respiratory support.

Emerging vaccine effectiveness estimates globally suggest reduced effectiveness against Omicron compared with prior variants [28-30], including an estimate of $70 \%$ vaccine effectiveness for two doses of the BNT162b2 vaccine to prevent Omicron hospitalizations in South Africa in NovemberDecember 2021 [9]. Using electronic health record data from sites across the United States, the VISION Network recently estimated mRNA vaccine effectiveness against Omicron hospitalizations to be to $52 \%$ for two vaccine doses with the second dose received within 180 days before illness onset, $38 \%$ for 2 doses received $>180$ days before illness onset, and $82 \%$ for 3 vaccine doses [11]. Prior studies largely relied on estimating predominant circulating SARS-CoV-2 variants from external data. This study adds vaccine effectiveness results against severe disease using sequence data from within the study and demonstrates strong protection against Omicron for three mRNA vaccine doses in the first several months after receipt of a third dose.

\section{Policy Implications}

These data indicate that Omicron-variant COVID-19 is a serious disease among those who are hospitalized, and preventative measures are indicated. Vaccination with existing mRNA vaccine formulations is an effective preventative measure against Omicron, both for the prevention of hospitalization, and among those hospitalized, for the prevention of progression to critical illness and 
medRxiv preprint doi: https://doi.org/10.1101/2022.02.06.22270558; this version posted February 7, 2022. The copyright holder for this preprint (which was not certified by peer review) is the author/funder, who has granted medRxiv a license to display the preprint in perpetuity.

All rights reserved. No reuse allowed without permission.

509

510

511

512

513

514

515

516

517 (new viral variants that are less susceptible to existing vaccines). Vaccine booster doses of the same

518

519

520

521

522

523

524 disease, and surveillance programs to identify viral variants will be essential to inform decisions about

525 booster vaccine policies and vaccine strain updates.

death. COVID-19 deaths in vaccinated individuals do occur, including with the Omicron variant, mostly in the elderly, the immunocompromised, or those with multiple medical comorbidities. These findings support recent recommendations in the United States for third mRNA vaccine doses for both immunocompetent [19] and immunocompromised [18] adults as a key approach to protecting populations against the Omicron variant.

The serial emergence of new SARS-CoV-2 variants, including Delta and Omicron, has challenged public health agencies to develop vaccine policies that counter the impact of waning immunity (the decline in protection of vaccine doses over time against the same variant) and viral immune evasion vaccine formulation used in the primary vaccine series are designed to counter waning immunity. Significant viral immune evasion would require new vaccine formulations targeting new variants to maintain protection. Boosters were implemented in several countries in response to COVID-19 spikes with emergence of the Delta variant. This study suggests that these booster doses were largely effective in preventing severe disease with both Delta and the subsequent Omicron variant. As the COVID-19 pandemic continues to evolve, routine vaccine effectiveness monitoring, especially against severe

\section{Conclusions}

528 In this large study of hospitalized adults in the United States, mRNA vaccines provided strong protection

529 against COVID-19 hospitalization caused by the Alpha, Delta, and Omicron variants. Furthermore,

530 vaccination reduced the risk for COVID-19 progressing to critical illness or death for each of the variants.

531 While disease severity for patients hospitalized with COVID-19 was somewhat lower for Omicron than 
medRxiv preprint doi: https://doi.org/10.1101/2022.02.06.22270558; this version posted February 7, 2022. The copyright holder for this preprint (which was not certified by peer review) is the author/funder, who has granted medRxiv a license to display the preprint in perpetuity.

All rights reserved. No reuse allowed without permission.

532

533

534

535

536

537

538

539

540

541

542

543

544

545

546

547

548

549

550

551

552

553

554

the Alpha and Delta variants, patients hospitalized with Omicron-variant COVID-19 still had a substantial risk for critical illness and death. These findings suggest that vaccination against COVID-19, including a third dose of an mRNA vaccine, is critical for protecting populations against COVID-19-associated morbidity and mortality.

\section{NOTES}

Contributions: Guarantors of this work include Dr. Self (protocol and data integrity), Dr. Tenforde (statistical analysis), Dr. Lauring (viral sequencing laboratory methods), and Dr. Chappell (RT-PCR laboratory methods). Contributions of each author include the following. Responsibility for decision to submit the manuscript: Self. Composed the initial manuscript draft: Lauring, Tenforde, Chappell, Patel, Self (the authors alone wrote the manuscript without outside assistance). Conceptualization of study methods: Lauring, Tenforde, Chappell, Talbot, Lindsell, Grijalva, Schrag, Kobayashi, Verani, Patel, Self. Data Collection: Lauring, Chappell, Gaglani, Ginde, McNeal, Ghamande, Douin, Talbot, Casey, Mohr, Zepeski, Shapiro, Gibbs, Files, Hager, Shehu, Prekker, Erickson, Exline, Gong, Mohamed, Johnson, Srinivasan, Steingrub, Peltan, Brown, Martin, Monto, Khan, Hough, Busse, ten Lohuis, Duggal, Wilson, Gordon, Qadir, Chang, Mallow, Rivas, Babcock, Kwon, Halasa, Grijalva, Rice, Stubblefield, Baughman, Womack, Rhoads, Self. Statistical analysis and data management: Tenforde, Lindsell, Hart, Zhu, Adams, Olson. Funding acquisition: Self. Critical review of the manuscript for important intellectual content: Lauring, Tenforde, Chappell, Gaglani, Ginde, McNeal, Ghamande, Douin, Talbot, Casey, Mohr, Zepeski, Shapiro, Gibbs, Files, Hager, Shehu, Prekker, Erickson, Exline, Gong, Mohamed, Johnson, Srinivasan, Steingrub, Peltan, Brown, Martin, Monto, Khan, Hough, Busse, ten Lohuis, Duggal, Wilson, Gordon, Qadir, Chang, Mallow, Rivas, Babcock, Kwon, Halasa, Grijalva, Rice, Stubblefield, Baughman, Womack, Rhoads, Lindsell, Hart, Zhu, Adams, Schrag, Olson, Kobayashi, Verani, Patel, Self. The corresponding 
medRxiv preprint doi: https://doi.org/10.1101/2022.02.06.22270558; this version posted February 7, 2022. The copyright holder for this preprint (which was not certified by peer review) is the author/funder, who has granted medRxiv a license to display the preprint in perpetuity.

All rights reserved. No reuse allowed without permission.

author (Dr. Self) attests that all listed authors meet authorship criteria and that no others meeting the criteria have been omitted.

Funding: Primary funding for this study was provided by the US Centers for Disease Control and Prevention (award 75D30121F00002 to Dr. Self). Scientists from the US CDC participating in all aspects of this study, including its design, analysis, interpretation of data, writing the report, and the decision to submit the article for publication. The REDCap data tool used in this study was supported by a Clinical and Translational Science Award (UL1 TR002243) from the National Center for Advancing Translational Sciences, National Institutes of Health.

Competing Interests: All authors have completed the ICMJE uniform disclosure form at www.icmje.org/coi_disclosure.pdf. The following declarations have been made. Adam S. Lauring reports consultant fees from Sanofi and fees from Roche for membership on a trial steering committee. James D. Chappell reports grant support from CDC and NIH. Manjusha Gaglani reports grant support from CDC. Adit A. Ginde reports grant support from CDC, NIH, DOD, and investigator-initiated grant support from AbbVie and Faron Pharmaceuticals. H. Keipp Talbot reports a grant from CDC. Jonathan D. Casey reports a grant (K23HL153584) from the National Institutes of Health (NIH). D. Clark Files reports consultant fees from Cytovale and membership on a Medpace Data Safety Monitoring Board (DSMB). David N. Hager reports a contract from CDC (via subcontract with VUMC) and salary support from Incyte Corporation, EMPACT Precision Medicine, and the Marcus Foundation. Matthew C. Exline reports talks on nutrition in COVID pneumonia at ASPEN conference sponsored by Abbott Labs. Michelle N. Gong reports grant support from CDC, funding from NHLBI, and fees for participating on a DSMB for Regeneron. Ithan D. Peltan reports grants from CDC, NIH, Intermountain Research and Medical Foundation, and Janssen Pharmaceuticals, institutional fees from Asahi Kasei Pharma and from Regeneron. Samuel M. Brown reports grants from CDC, Sedana, Janssen, NIH, and the Department of Defense (DOD); fees from Hamilton for chairing a DSMB; institutional fees from Faron; book royalties from Oxford University and 
medRxiv preprint doi: https://doi.org/10.1101/2022.02.06.22270558; this version posted February 7, 2022. The copyright holder for this preprint (which was not certified by peer review) is the author/funder, who has granted medRxiv a license to display the preprint in perpetuity.

All rights reserved. No reuse allowed without permission.

579 Brigham Young University; and personal fees from New York University for service on a DSMB. Emily T.

580 Martin reports a grant from Merck for unrelated work. Akram Khan reports grants from Gilead, Ely Lily,

581 United Therapeutics, Johnson \& Johnson (Actelion), Liquidia Pharmaceuticals, and 4D Medical. Steven Y.

582 Chang was a speaker for La Jolla Pharmaceuticals and a Consultant for PureTech Health. Jennie H. Kwon

583 reports grant support from NIH/NIAID (1K23 AI137321-01A1). Natasha Halasa reports grants from CDC,

584 Sanofi and Quidel. Carlos G. Grijalva reports consultant fees from Pfizer, Merck, and Sanofi-Pasteur and

585 grants from Campbell Alliance/Syneos Health, CDC, NIH, FDA, AHRQ, and Sanofi. Todd Rice reports grant

586 support from CDC. Christopher J. Lindsell reports grants from CDC, NIH, DoD, and the Marcus

587 Foundation; organizational contract fees from bioMerieux, Endpoint LLC, and Entegrion, Inc.; and a

588 patent issued to Cincinnati Children's Hospital Medical Center for risk stratification in sepsis and septic

589 shock. Wesley H. Self reports grant funding from CDC for this work, grants and consultant fees from

590 Merck outside this work and consultant fees from Aerpio Pharmaceuticals outside this work. No other

591 potential conflicts of interest were disclosed.

592 Patient Consent: not applicable.

593 Ethical Approval: This program was approved as a public health surveillance activity with waiver of

594 informed consent by institutional review boards at the US Centers for Disease Control and Prevention

595 (CDC), the program's coordinating center at Vanderbilt University Medical Center and each participating

596 site.

Data Sharing: No additional data are available. 
medRxiv preprint doi: https://doi.org/10.1101/2022.02.06.22270558; this version posted February 7, 2022. The copyright holder for this preprint (which was not certified by peer review) is the author/funder, who has granted medRxiv a license to display the preprint in perpetuity.

All rights reserved. No reuse allowed without permission.

\section{REFERENCES}

600

601

602

603

604

605

606

607

608

609

610

611

612

613

614

615

616

617

618

619

620

621

622

623

624

625

626

627

628

629

630

631

632

633

1 Lauring AS, Hodcroft EB. Genetic Variants of SARS-CoV-2-What Do They Mean? JAMA 2021;325:529. doi:10.1001/jama.2020.27124

2 Tracking SARS-CoV-2 variants. https://www.who.int/health-topics/typhoid/tracking-SARS-CoV-2variants (accessed 26 Oct 2021).

3 GISAID - hCov19 Variants. https://www.gisaid.org/hcov19-variants/ (accessed 26 Oct 2021).

4 Sheikh A, McMenamin J, Taylor B, et al. SARS-CoV-2 Delta VOC in Scotland: demographics, risk of hospital admission, and vaccine effectiveness. The Lancet 2021;397:2461-2. doi:10.1016/S01406736(21)01358-1

5 Twohig KA, Nyberg T, Zaidi A, et al. Hospital admission and emergency care attendance risk for SARS-CoV-2 delta (B.1.617.2) compared with alpha (B.1.1.7) variants of concern: a cohort study. The Lancet Infectious Diseases 2022;22:35-42. doi:10.1016/S1473-3099(21)00475-8

6 Taylor CA, Patel K, Pham H, et al. Severity of Disease Among Adults Hospitalized with LaboratoryConfirmed COVID-19 Before and During the Period of SARS-CoV-2 B.1.617.2 (Delta) Predominance - COVID-NET, 14 States, January-August 2021. MMWR Morb Mortal Wkly Rep 2021;70:1513-9. doi:10.15585/mmwr.mm7043e1

7 Viana R, Moyo S, Amoako DG, et al. Rapid epidemic expansion of the SARS-CoV-2 Omicron variant in southern Africa. Nature Published Online First: 7 January 2022. doi:10.1038/s41586-022-04411-y

8 Lewnard JA, Hong VX, Patel MM, et al. Clinical outcomes among patients infected with Omicron (B.1.1.529) SARS-CoV-2 variant in southern California. Epidemiology 2022. doi:10.1101/2022.01.11.22269045

9 Collie S, Champion J, Moultrie H, et al. Effectiveness of BNT162b2 Vaccine against Omicron Variant in South Africa. N Engl J Med 2021;:NEJMc2119270. doi:10.1056/NEJMc2119270

10 Johnson AG, Amin AB, Ali AR, et al. COVID-19 Incidence and Death Rates Among Unvaccinated and Fully Vaccinated Adults with and Without Booster Doses During Periods of Delta and Omicron Variant Emergence - 25 U.S. Jurisdictions, April 4-December 25, 2021. MMWR Morb Mortal Wkly Rep 2022;71:132-8. doi:10.15585/mmwr.mm7104e2

11 Thompson MG, Natarajan K, Irving SA, et al. Effectiveness of a Third Dose of mRNA Vaccines Against COVID-19-Associated Emergency Department and Urgent Care Encounters and Hospitalizations Among Adults During Periods of Delta and Omicron Variant Predominance - VISION Network, 10 States, August 2021-January 2022. MMWR Morb Mortal Wkly Rep 2022;71:139-45. doi:10.15585/mmwr.mm7104e3

12 Tenforde MW, Self WH, Naioti EA, et al. Sustained Effectiveness of Pfizer-BioNTech and Moderna Vaccines Against COVID-19 Associated Hospitalizations Among Adults - United States, March-July 2021. MMWR Morb Mortal Wkly Rep 2021;70:1156-62. doi:10.15585/mmwr.mm7034e2 
medRxiv preprint doi: https://doi.org/10.1101/2022.02.06.22270558; this version posted February 7, 2022. The copyright holder for this preprint (which was not certified by peer review) is the author/funder, who has granted medRxiv a license to display the preprint in perpetuity.

All rights reserved. No reuse allowed without permission.

634

635

636

637

638

639

640

641

642

643

644

645

646

647

648

649

650

651

652

653

654

655

656

657

658

659

660

661

662

663

664

665

666

667

668

669

13 Tenforde MW, Self WH, Adams K, et al. Association Between mRNA Vaccination and COVID-19 Hospitalization and Disease Severity. JAMA 2021;326:2043. doi:10.1001/jama.2021.19499

14 Tenforde MW, Patel MM, Ginde AA, et al. Effectiveness of Severe Acute Respiratory Syndrome Coronavirus 2 Messenger RNA Vaccines for Preventing Coronavirus Disease 2019 Hospitalizations in the United States. Clinical Infectious Diseases 2021;:ciab687. doi:10.1093/cid/ciab687

15 Self WH, Tenforde MW, Rhoads JP, et al. Comparative Effectiveness of Moderna, Pfizer-BioNTech, and Janssen (Johnson \& Johnson) Vaccines in Preventing COVID-19 Hospitalizations Among Adults Without Immunocompromising Conditions - United States, March-August 2021. MMWR Morb Mortal Wkly Rep 2021;70:1337-43. doi:10.15585/mmwr.mm7038e1

16 Patel MK, Bergeri I, Bresee JS, et al. Evaluation of post-introduction COVID-19 vaccine effectiveness: Summary of interim guidance of the World Health Organization. Vaccine 2021;39:4013-24. doi:10.1016/j.vaccine.2021.05.099

17 Lewnard JA, Patel MM, Jewell NP, et al. Theoretical Framework for Retrospective Studies of the Effectiveness of SARS-CoV-2 Vaccines. Epidemiology 2021;32:508-17. doi:10.1097/EDE.0000000000001366

18 Food and Drug Administratin. Coronavirus (COVID-19) Update: FDA Authorizes Additional Vaccine Dose for Certain Immunocompromised Individuals. FDA. 2021.https://www.fda.gov/newsevents/press-announcements/coronavirus-covid-19-update-fda-authorizes-additional-vaccine-dosecertain-immunocompromised (accessed 31 Jan 2022).

19 Food and Drug Administration. Coronavirus (COVID-19) Update: FDA Expands Eligibility for COVID19 Vaccine Boosters. FDA. 2021.https://www.fda.gov/news-events/pressannouncements/coronavirus-covid-19-update-fda-expands-eligibility-covid-19-vaccine-boosters (accessed 31 Jan 2022).

20 Tenforde MW, Patel MM, Gaglani M, et al. Effectiveness of a Third Dose of Pfizer-BioNTech and Moderna Vaccines in Preventing COVID-19 Hospitalization Among Immunocompetent and Immunocompromised Adults - United States, August-December 2021. MMWR Morb Mortal Wkly Rep 2022;71:118-24. doi:10.15585/mmwr.mm7104a2

21 US Food and Drug Administration. CDC 2019-Novel Coronavirus (2019-nCoV) Real-Time RT-PCR Diagnostic Panel. 2021.https://www.fda.gov/media/134922/download (accessed 26 May 2021).

22 Quick J. nCoV-2019 sequencing protocol v3 (LoCost). protocols.io. 2020.https://www.protocols.io/view/ncov-2019-sequencing-protocol-v3-locost-bh42j8ye (accessed 26 May 2021).

23 Rambaut A, Holmes EC, O’Toole Á, et al. A dynamic nomenclature proposal for SARS-CoV-2 lineages to assist genomic epidemiology. Nat Microbiol 2020;5:1403-7. doi:10.1038/s41564-020-0770-5

24 Marshall JC, Murthy S, Diaz J, et al. A minimal common outcome measure set for COVID-19 clinical research. The Lancet Infectious Diseases 2020;20:e192-7. doi:10.1016/S1473-3099(20)30483-7 
medRxiv preprint doi: https://doi.org/10.1101/2022.02.06.22270558; this version posted February 7, 2022. The copyright holder for this preprint

(which was not certified by peer review) is the author/funder, who has granted medRxiv a license to display the preprint in perpetuity.

All rights reserved. No reuse allowed without permission.

67025 Centers for Disease Control and Prevention. COVID Data Tracker. 2022.https://covid.cdc.gov/covid671 data-tracker/\#datatracker-home (accessed 31 Jan 2022).

67226 Griffith GJ, Morris TT, Tudball MJ, et al. Collider bias undermines our understanding of COVID-19

673 disease risk and severity. Nat Commun 2020;11:5749. doi:10.1038/s41467-020-19478-2

67427 Sullivan SG, Tchetgen Tchetgen EJ, Cowling BJ. Theoretical Basis of the Test-Negative Study Design 675 for Assessment of Influenza Vaccine Effectiveness. Am J Epidemiol 2016;184:345-53.

676 doi:10.1093/aje/kww064

67728 Rufino J, Baquero C, Frey D, et al. Using Survey Data to Estimate the Impact of the Omicron Variant

678 on Vaccine Efficacy against COVID-19 Infection. Public and Global Health 2022.

679 doi:10.1101/2022.01.21.22269636

68029 Tseng HF, Ackerson BK, Luo Y, et al. Effectiveness of mRNA-1273 against SARS-CoV-2 omicron and 681 delta variants. Infectious Diseases (except HIV/AIDS) 2022. doi:10.1101/2022.01.07.22268919

682

30 Young-Xu Y. Effectiveness of mRNA COVID-19 Vaccines against Omicron among Veterans. Infectious 683 Diseases (except HIV/AIDS) 2022. doi:10.1101/2022.01.15.22269360 
medRxiv preprint doi: https://doi.org/10.1101/2022.02.06.22270558; this version posted February 7, 2022. The copyright holder for this preprint (which was not certified by peer review) is the author/funder, who has granted medRxiv a license to display the preprint in perpetuity. All rights reserved. No reuse allowed without permission.

Table 1. Characteristics of patients included in the evaluation of vaccine effectiveness to preventing COVID-19 hospitalizations, including hospitalized patients without COVID-19 (controls) and hospitalized patients with COVID-19 (cases) during the Alpha period (March 11 - July 3, 2021), Delta period (July 4 December 25, 2021), and Omicron period (December 26, 2021- January 14, 2022). (Baseline characteristics for cases limited to those with a sequencing-confirmed variant are shown in Table S4.)

\begin{tabular}{|c|c|c|c|c|}
\hline Patient Characteristics & $\begin{array}{l}\text { All controls } \\
(n=5962)\end{array}$ & $\begin{array}{l}\text { Alpha cases } \\
(n=1072)\end{array}$ & $\begin{array}{l}\text { Delta cases } \\
(n=3951)\end{array}$ & $\begin{array}{l}\text { Omicron cases } \\
(n=559)\end{array}$ \\
\hline Age in years, median (IQR) & $63(50-72)$ & $56(43-65.5)$ & $57(43-69)$ & $62(49-73)$ \\
\hline Female sex, No. (\%) & 2975 (49.9) & $519(48.4)$ & $1803(45.6)$ & $264(47.2)$ \\
\hline \multicolumn{5}{|l|}{ Race and ethnicity, No. (\%) } \\
\hline Non-Hispanic White & $3611(60.6)$ & $484(45.1)$ & $2183(55.3)$ & $279(49.9)$ \\
\hline Non-Hispanic Black & $1240(20.8)$ & $285(26.6)$ & $820(20.8)$ & $127(22.7)$ \\
\hline Hispanic, any race & $772(12.9)$ & $220(20.5)$ & $695(17.6)$ & $111(19.9)$ \\
\hline Non-Hispanic, Other & $253(4.2)$ & $63(5.9)$ & $179(4.5)$ & $33(5.9)$ \\
\hline Unknown & $86(1.4)$ & $20(1.9)$ & $74(1.9)$ & $9(1.6)$ \\
\hline \multicolumn{5}{|l|}{ US Census region, No. (\%) } \\
\hline Northeast & $885(14.8)$ & $158(14.7)$ & $686(17.4)$ & $159(28.4)$ \\
\hline South & $2371(39.8)$ & $395(36.8)$ & $1544(39.1)$ & $196(35.1)$ \\
\hline Midwest & $1374(23.0)$ & $248(23.1)$ & $978(24.8)$ & $104(18.6)$ \\
\hline West & $1332(22.3)$ & $271(25.3)$ & $743(18.8)$ & $100(17.9)$ \\
\hline $\begin{array}{l}\text { Resident of long-term care } \\
\text { facility, No. / Total (\%) }\end{array}$ & $321 / 5778(5.6)$ & $25 / 1039(2.4)$ & $\begin{array}{l}120 / 3795 \\
(3.2)\end{array}$ & $30 / 534(5.6)$ \\
\hline $\begin{array}{l}\geq 1 \text { prior hospitalization in past } \\
\text { year, No. / Total (\%) }\end{array}$ & $3031 / 5537(54.7)$ & $\begin{array}{l}282 / 956 \\
(29.5)\end{array}$ & $\begin{array}{l}1015 / 3682 \\
(27.6)\end{array}$ & $226 / 535(42.2)$ \\
\hline $\begin{array}{l}\text { Current tobacco use, No. / } \\
\text { Total (\%) }\end{array}$ & $1016 / 5302(19.2)$ & $\begin{array}{l}103 / 887 \\
(11.6)\end{array}$ & $\begin{array}{l}366 / 3451 \\
(10.6)\end{array}$ & $59 / 470(12.6)$ \\
\hline $\begin{array}{l}\text { Number of chronic medical } \\
\text { conditions } \ddagger \text {, median (IQR) }\end{array}$ & $2(1-3)$ & $1(1-3)$ & $1(0-3)$ & $2(1-3)$ \\
\hline \multicolumn{5}{|l|}{$\begin{array}{l}\text { Categories of medical } \\
\text { conditions } \ddagger\end{array}$} \\
\hline $\begin{array}{l}\text { Chronic cardiovascular } \\
\text { disease }\end{array}$ & $4158(69.7)$ & $589(54.9)$ & $2141(54.2)$ & $359(64.2)$ \\
\hline Chronic pulmonary disease & $1973(33.1)$ & $231(21.5)$ & $827(20.9)$ & $151(27.0)$ \\
\hline Diabetes mellitus & 1962 (32.9) & $316(29.5)$ & $1135(28.7)$ & $164(29.3)$ \\
\hline $\begin{array}{l}\text { Immunocompromising } \\
\text { condition* }\end{array}$ & $1458(24.5)$ & $172(16.0)$ & $659(16.7)$ & $138(24.7)$ \\
\hline Obesity, No. / Total (\%) & $2391 / 5900(40.5)$ & $\begin{array}{l}616 / 1056 \\
(58.3)\end{array}$ & $\begin{array}{l}2099 / 3909 \\
(53.7)\end{array}$ & $260 / 556(46.8)$ \\
\hline \multicolumn{5}{|l|}{ Vaccination status } \\
\hline Unvaccinated & $2054(34.5)$ & $953(88.9)$ & $2871(72.7)$ & $268(47.9)$ \\
\hline 2 doses $(<150$ days $)$ & $2029(34.0)$ & $119(11.1)$ & $352(8.9)$ & $34(6.1)$ \\
\hline 2 doses ( $\geq 150$ days) & $1411(23.7)$ & $0(0)$ & $667(16.9)$ & $177(31.7)$ \\
\hline 3 doses & $468(7.8)$ & $0(0)$ & $61(1.5)$ & $80(14.3)$ \\
\hline \multicolumn{5}{|l|}{$\begin{array}{l}\text { If vaccinated, vaccine product } \\
\text { received, No. / Total (\%) }\end{array}$} \\
\hline BNT162b2 (Pfizer-BioNTech) & $2269 / 3908(58.1)$ & $81 / 119(68.1)$ & $708 / 1080$ & $203 / 291(69.8)$ \\
\hline
\end{tabular}


medRxiv preprint doi: https://doi.org/10.1101/2022.02.06.22270558; this version posted February 7, 2022. The copyright holder for this preprint (which was not certified by peer review) is the author/funder, who has granted medRxiv a license to display the preprint in perpetuity. All rights reserved. No reuse allowed without permission.

\begin{tabular}{|l|l|l|l|l|}
\hline mRNA-1273 (Moderna) & $1615 / 3908(41.3)$ & $37 / 119(31.1)$ & $\begin{array}{l}(65.6) \\
(34.1)\end{array}$ & $84 / 291(28.9)$ \\
\hline Mixed products & $24 / 3908(0.6)$ & $1 / 119(0.8)$ & $4 / 1080(0.4)$ & $4 / 291(1.4)$ \\
\hline $\begin{array}{l}\text { Days since dose 3 if 3 doses } \\
\text { received, median (IQR) }\end{array}$ & $41(23-64)$ & -- & $38(23-65)$ & $69.5(41.5-97)$ \\
\hline
\end{tabular}

Definitions: IQR = interquartile range; US = United States

*Immunocompromising conditions were obtained using structured medical chart review and defined as 1 or more of the following: active solid organ cancer (active cancer defined as treatment for the cancer or newly diagnosed cancer in the past 6 months), active hematologic cancer, HIV infection without AIDS, AIDS, congenital immunodeficiency syndrome, previous splenectomy, previous solid organ transplant, immunosuppressive medication, systemic lupus erythematosus, rheumatoid arthritis, psoriasis, scleroderma, or inflammatory bowel disease, including Crohn's disease or ulcerative colitis. 
Table 2. In-hospital clinical outcomes among adults hospitalized with COVID-19 by variant group (Alpha, Delta, Omicron).

\begin{tabular}{|c|c|c|c|c|c|c|c|c|c|}
\hline \multirow[t]{2}{*}{ Outcome } & \multicolumn{3}{|c|}{ Alpha Group ( $n=1060)$} & \multicolumn{3}{|c|}{ Delta Group ( $n=3788$ ) } & \multicolumn{3}{|c|}{ Omicron Group $(n=565)$} \\
\hline & Vaccinated & Unvaccinated & P* & Vaccinated & Unvaccinated & $\mathrm{P}^{*}$ & Vaccinated & Unvaccinated & $\mathbf{P}^{*}$ \\
\hline Death, no. (\%) & $5 / 116(4.3)$ & $76 / 944(8.1)$ & 0.15 & $\begin{array}{l}138 / 1045 \\
(13.2)\end{array}$ & $\begin{array}{l}323 / 2743 \\
(11.8)\end{array}$ & 0.23 & $\begin{array}{l}15 / 293 \\
(5.1)\end{array}$ & $25 / 272(9.2)$ & 0.059 \\
\hline $\begin{array}{l}\text { Invasive mechanical } \\
\text { ventilation, no. (\%) }\end{array}$ & $7 / 116(6.0)$ & $\begin{array}{l}201 / 944 \\
(21.3)\end{array}$ & $<0.001$ & $\begin{array}{l}152 / 1045 \\
(14.5)\end{array}$ & $\begin{array}{l}681 / 2743 \\
(24.8)\end{array}$ & $<0.001$ & $\begin{array}{l}35 / 293 \\
(11.9)\end{array}$ & $49 / 272(18.0)$ & 0.043 \\
\hline $\begin{array}{l}\text { Composite of death or } \\
\text { invasive mechanical } \\
\text { ventilation, no. (\%) }\end{array}$ & $\begin{array}{l}10 / 116 \\
(8.6)\end{array}$ & $\begin{array}{l}218 / 944 \\
(23.1)\end{array}$ & $<0.001$ & $\begin{array}{l}210 / 1045 \\
(20.1)\end{array}$ & $\begin{array}{l}748 / 2743 \\
(27.3)\end{array}$ & $<0.001$ & $\begin{array}{l}42 / 293 \\
(14.3)\end{array}$ & $54 / 272(19.9)$ & 0.08 \\
\hline $\begin{array}{l}\text { Admitted to intensive } \\
\text { care unit, No. (\%) }\end{array}$ & $\begin{array}{l}24 / 116 \\
(20.7)\end{array}$ & $\begin{array}{l}353 / 944 \\
(37.4)\end{array}$ & $<0.001$ & $\begin{array}{l}321 / 1045 \\
(30.7)\end{array}$ & $\begin{array}{l}1179 / 2742 \\
(43.0)\end{array}$ & $<0.001$ & $\begin{array}{l}66 / 293 \\
(22.5)\end{array}$ & $89 / 271(32.8)$ & 0.006 \\
\hline $\begin{array}{l}\text { Non-invasive } \\
\text { ventilation, no. (\%) }\end{array}$ & $\begin{array}{l}15 / 116 \\
(12.9)\end{array}$ & $\begin{array}{l}167 / 944 \\
(17.7)\end{array}$ & 0.20 & $\begin{array}{l}151 / 1045 \\
(14.4)\end{array}$ & $\begin{array}{l}470 / 2743 \\
(17.1)\end{array}$ & 0.046 & $\begin{array}{l}39 / 293 \\
(13.3)\end{array}$ & $43 / 272(15.8)$ & 0.40 \\
\hline $\begin{array}{l}\text { High-flow oxygen } \\
\text { therapy, no. (\%) }\end{array}$ & $\begin{array}{l}15 / 116 \\
(12.9)\end{array}$ & $\begin{array}{l}324 / 944 \\
(34.3)\end{array}$ & $<0.001$ & $\begin{array}{l}289 / 1045 \\
(27.7)\end{array}$ & $\begin{array}{l}1148 / 2743 \\
(41.9)\end{array}$ & $<0.001$ & $\begin{array}{l}59 / 293 \\
(20.1)\end{array}$ & $84 / 272(30.9)$ & 0.003 \\
\hline Vasopressors, no. (\%) & $5 / 116(4.3)$ & $\begin{array}{l}191 / 944 \\
(20.2)\end{array}$ & $<0.001$ & $\begin{array}{l}155 / 1045 \\
(14.8)\end{array}$ & $\begin{array}{l}647 / 2743 \\
(23.6)\end{array}$ & $<0.001$ & $\begin{array}{l}36 / 293 \\
(12.3)\end{array}$ & $46 / 272(16.9)$ & 0.12 \\
\hline $\begin{array}{l}\text { New renal replacement } \\
\text { therapy, no. (\%) }\end{array}$ & $6 / 116(5.1)$ & $43 / 944(4.6)$ & 0.91 & $\begin{array}{l}49 / 1045 \\
(4.7)\end{array}$ & $\begin{array}{l}159 / 2743 \\
(5.8)\end{array}$ & 0.18 & $\begin{array}{l}14 / 293 \\
(4.8)\end{array}$ & $12 / 272(4.4)$ & 0.84 \\
\hline $\begin{array}{l}\text { Hospital length among } \\
\text { survivors, median (IQR) }\end{array}$ & $5(3-8)$ & $5(3-9)$ & 0.56 & $5(3-9)$ & $6(3-10)$ & $<0.001$ & $5(3-9)$ & $6(3-11)$ & 0.050 \\
\hline $\begin{array}{l}\text { Venous } \\
\text { thromboembolic event, } \\
\text { No. (\%) }\end{array}$ & $7 / 116(6.0)$ & $55 / 944(5.8)$ & 0.93 & $\begin{array}{l}46 / 1045 \\
(4.4)\end{array}$ & $\begin{array}{l}250 / 2743 \\
(9.1)\end{array}$ & $<0.001$ & $\begin{array}{l}15 / 293 \\
(5.1)\end{array}$ & $22 / 272(8.1)$ & 0.15 \\
\hline Stroke, No. (\%) & $0 / 116(0)$ & $18 / 944(1.9)$ & 0.13 & $\begin{array}{l}9 / 1045 \\
(0.9)\end{array}$ & $44 / 2743(1.6)$ & 0.08 & $3 / 293(1.0)$ & $4 / 272(1.5)$ & 0.63 \\
\hline $\begin{array}{l}\text { Myocardial infarction, } \\
\text { No. (\%) }\end{array}$ & $1 / 116(0.9)$ & $19 / 944(2.0)$ & 0.39 & $\begin{array}{l}29 / 1045 \\
(2.8)\end{array}$ & $58 / 2743(2.1)$ & 0.23 & $5 / 293(1.7)$ & $5 / 272(1.8)$ & 0.91 \\
\hline
\end{tabular}

* P-values obtained using chi-square testing, not adjusting for other factors. 
Figure 1. Sequenced SARS-CoV-2 variants by week among patients with COVID-19 enrolled in this study and hospitalized between March 11 , 2021 and January 14, 2022 in 21 hospitals in the United States. Vertical dashed lines at July 4, 2021 and December 25, 2021 represent the start of the Delta period and Omicron period, respectively. This figure includes all cases enrolled in the program with a sequencing result, without restriction to cases included in the vaccine effectiveness analyses. SARS-CoV-2 variant lineages were identified for 3017 cases, including alpha (299), beta (8), delta (2209), gamma (52), omicron (286), and lineage not designated as variant of concern (163).

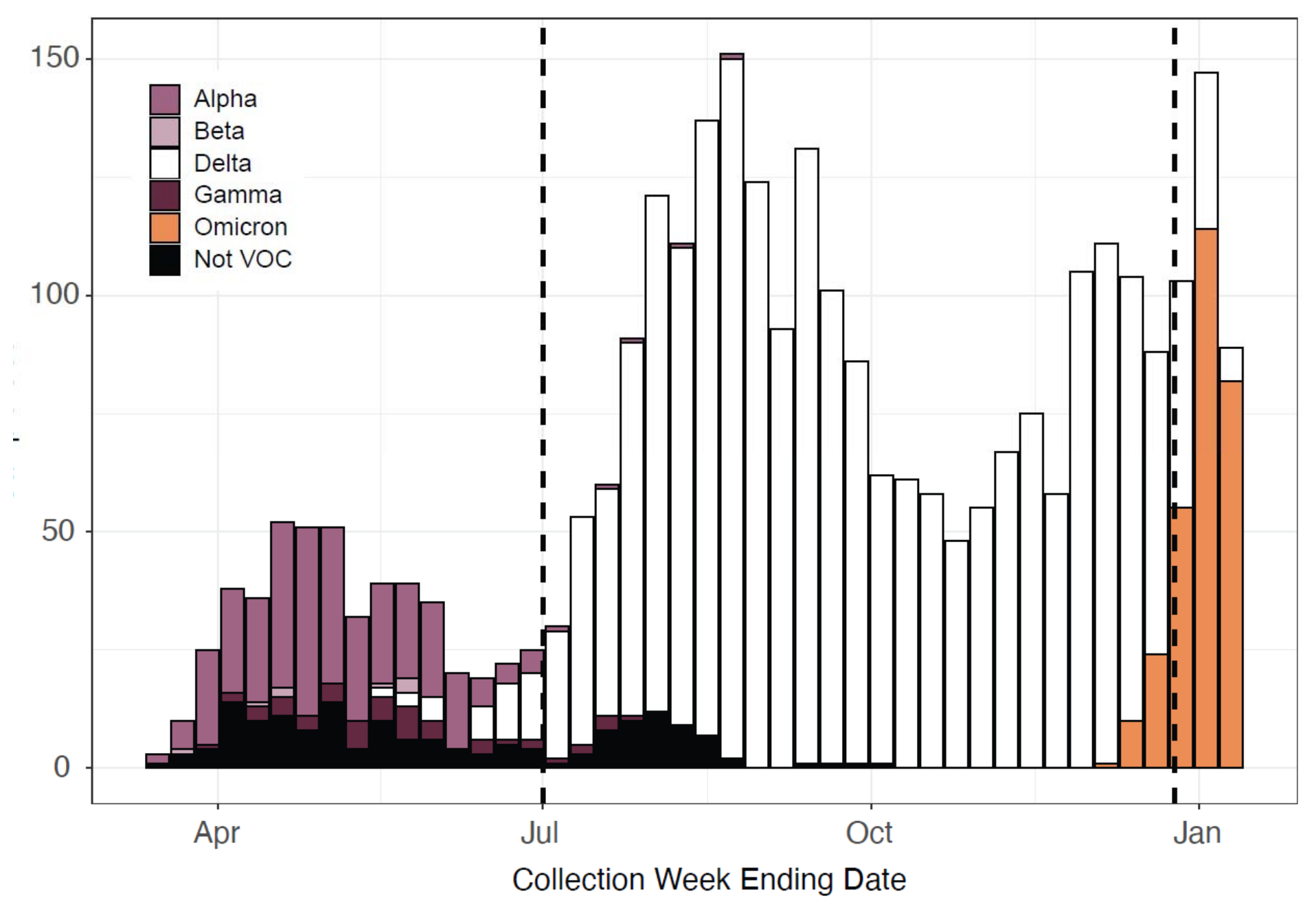


medRxiv preprint doi: https://doi.org/10.1101/2022.02.06.22270558; this version posted February 7, 2022. The copyright holder for this preprint (which was not certified by peer review) is the author/funder, who has granted medRxiv a license to display the preprint in perpetuity.

All rights reserved. No reuse allowed without permission.

Figure 2. Vaccine effectiveness of COVID-19 mRNA vaccines to prevent COVID-19 hospitalizations by variant group, including Alpha, Delta, and Omicron.

\begin{tabular}{|c|c|c|c|c|}
\hline \multirow[b]{2}{*}{ Group } & \multicolumn{2}{|c|}{ COVID-19 Hospitalizations } & \multirow[b]{2}{*}{$\begin{array}{l}\text { Adjusted VE, \% } \\
(95 \% \mathrm{Cl})\end{array}$} & \\
\hline & $\begin{array}{l}\text { No. vaccinated/ } \\
\text { Total cases (\%) }\end{array}$ & $\begin{array}{l}\text { No. vaccinated/ Total } \\
\text { controls (\%) }\end{array}$ & & \\
\hline \multicolumn{5}{|c|}{ Alpha period (March $11-$ July 3, 2021) - 2 doses } \\
\hline Overall & $119 / 1072(11.0)$ & $893 / 1738(51.4)$ & $85(82-88)$ & $=$ \\
\hline \multicolumn{5}{|l|}{ By immunocompromised statusł } \\
\hline Yes & $49 / 172(28.5)$ & $218 / 398(54.8)$ & $58(33-73)$ & ——— \\
\hline No & $70 / 900(7.8)$ & $675 / 1340(50.4)$ & $90(87-93)$ & + \\
\hline \multicolumn{5}{|l|}{ By age group } \\
\hline $18-64$ & $46 / 779(5.9)$ & $357 / 985(36.2)$ & $87(82-91)$ & - \\
\hline$\geq 65$ & $73 / 293(24.9)$ & $536 / 753(71.2)$ & $85(80-89)$ & $\rightarrow-$ \\
\hline \multicolumn{5}{|l|}{ By chronic medical conditions $\S$} \\
\hline 0 chronic conditions & $4 / 262(1.5)$ & $65 / 208(31.3)$ & $96(89-99)$ & $\rightarrow$ \\
\hline$\geq 1$ chronic condition & $115 / 810(14.2)$ & $828 / 1530(54.1)$ & $83(79-87)$ & - \\
\hline \multicolumn{5}{|l|}{ By mRNA vaccine product } \\
\hline BNT162b2 (Pfizer-BioNTech) & $81 / 1034(7.8)$ & $519 / 1364(38.0)$ & $82(77-86)$ & -1 \\
\hline mRNA-1273 (Moderna) & $37 / 990(3.7)$ & $374 / 1219(30.7)$ & $90(85-93)$ & - 름 \\
\hline \multicolumn{5}{|c|}{ Delta period (July 4- December 25, 2021) - 2 doses } \\
\hline Overall & $1019 / 3890(26.2)$ & $2389 / 3509(68.1)$ & $85(83-87)$ & $-\frac{1}{-1}$ \\
\hline 2 doses ( $\leq 150$ days) & $352 / 3223(10.9)$ & $1103 / 2223(49.6)$ & $88(86-90)$ & 둘 \\
\hline 2 doses (>150 days) & $667 / 3538(18.9)$ & $1286 / 2406(53.4)$ & $81(78-84)$ & 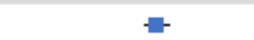 \\
\hline \multicolumn{5}{|l|}{ By immunocompromised status $\neq$} \\
\hline Yes & $329 / 614(53.6)$ & $570 / 780(73.1)$ & $63(52-71)$ & $\longrightarrow$ \\
\hline No & $690 / 3276(21.1)$ & $1819 / 2729(66.7)$ & $88(86-90)$ & $=$ \\
\hline \multicolumn{5}{|l|}{ By age group } \\
\hline $18-64$ & $427 / 2586(16.5)$ & $1152 / 1957(58.9)$ & $88(86-89)$ & a \\
\hline$\geq 65$ & $592 / 1304(45.4)$ & $1237 / 1552(79.7)$ & $81(77-84)$ & $-\frac{\mathrm{n}}{\mathrm{n}}$ \\
\hline \multicolumn{5}{|l|}{ By chronic medical conditions§ } \\
\hline 0 chronic conditions & $63 / 1057(6.0)$ & $210 / 364(57.7)$ & $96(95-98)$ & 룰 \\
\hline$\geq 1$ chronic condition & $956 / 2833(33.7)$ & $2179 / 3145(69.3)$ & $80(78-82)$ & $=$ \\
\hline \multicolumn{5}{|l|}{ By mRNA vaccine product } \\
\hline BNT162b2 (Pfizer-BioNTech) & $668 / 3539(18.9)$ & $1353 / 2473(54.7)$ & $82(80-84)$ & $=$ \\
\hline mRNA-1273 (Moderna) & $347 / 3218(10.8)$ & $1033 / 2153(48.0)$ & $88(86-90)$ & 틀 \\
\hline \multicolumn{5}{|c|}{ Delta period (July 4- December 25,2021 ) - 3 doses } \\
\hline Overall & $61 / 2932(2.1)$ & $333 / 1453(22.9)$ & $94(92-95)$ & - \\
\hline Immunocompromised & $45 / 330(13.6)$ & $165 / 375(44.0)$ & $87(78-92)$ & - \\
\hline Immunocompetent & $16 / 2602(0.6)$ & $168 / 1078(15.6)$ & $97(95-98)$ & - \\
\hline \multicolumn{5}{|c|}{ Omicron period (December 26 - January 14, 2022) - 2 doses } \\
\hline Overall & $211 / 479(44.1)$ & $158 / 247(64.0)$ & $65(51-75)$ & $\longrightarrow$ \\
\hline Immunocompetent only & $156 / 382(40.8)$ & $116 / 191(60.7)$ & $66(49-77)$ & $\longrightarrow$ \\
\hline \multicolumn{5}{|c|}{ Omicron period (December 26- January 14, 2022) - 3 doses } \\
\hline Overall & $80 / 348(23.0)$ & $135 / 224(60.3)$ & $86(77-91)$ & - 믄 \\
\hline \multirow[t]{3}{*}{ Immunocompetent only } & $39 / 265(14.7)$ & $76 / 151(50.3)$ & $86(75-92)$ & $\longrightarrow$ \\
\hline & & & 0 & 50 \\
\hline & & & & $\%(95 \% \mathrm{Cl})$ \\
\hline
\end{tabular}

Definitions: $V E=$ vaccine effectiveness

$¥$ Immunocompromising conditions were obtained using structured medical chart review and defined as 1 or more of the following: active solid organ cancer (active cancer defined as treatment for the cancer or newly diagnosed cancer in the past 6 months), active hematologic cancer, HIV infection without AIDS, AIDS, congenital immunodeficiency syndrome, previous splenectomy, previous solid organ transplant, 
medRxiv preprint doi: https://doi.org/10.1101/2022.02.06.22270558; this version posted February 7, 2022. The copyright holder for this preprint (which was not certified by peer review) is the author/funder, who has granted medRxiv a license to display the preprint in perpetuity.

All rights reserved. No reuse allowed without permission.

immunosuppressive medication, systemic lupus erythematosus, rheumatoid arthritis, psoriasis, scleroderma, or inflammatory bowel disease, including Crohn's disease or ulcerative colitis.

$\S$ Chronic medical conditions were obtained using structured medical chart review and defined as conditions within 1 or more of the following categories: cardiovascular disease, neurologic disease, pulmonary disease, gastrointestinal disease, endocrine disease, renal disease, hematologic disease, malignancy, immunosuppression not captured in other categories, autoimmune condition, or other condition (sarcoidosis, amyloidosis, or unintentional weight loss $\geq 10$ pounds $(4.5 \mathrm{~kg}$ ) in the last 90 days). 
medRxiv preprint doi: https://doi.org/10.1101/2022.02.06.22270558; this version posted February 7, 2022. The copyright holder for this preprint (which was not certified by peer review) is the author/funder, who has granted medRxiv a license to display the preprint in perpetuity.

All rights reserved. No reuse allowed without permission.

Figure 3. COVID-19 disease severity during index hospitalization among adults hospitalized with COVID19, by SARS-CoV-2 variant for (A) unvaccinated patients, and (B) vaccinated patients. Disease severity was classified based on the highest severity level reached on the World Health Organization Clinical Progression Scale, which ranged from hospitalized without oxygen therapy (lowest level) to death (highest level). Among unvaccinated patients, severity was higher for Delta than Alpha (aPOR: 1.28, 95\% $\mathrm{Cl}: 1.11$ to 1.46 ), lower for Omicron than Delta (aPOR: $0.61,95 \% \mathrm{Cl}: 0.49$ to 0.77 ). For each variant, severity was lower for vaccinated patients ( 2 or 3 doses of an mRNA vaccine) than unvaccinated patients, including for Alpha (aPOR: $0.33,95 \% \mathrm{Cl}: 0.23$ to 0.49 ), Delta (aPOR: $0.44,95 \% \mathrm{Cl}: 0.37$ to 0.51 ), and Omicron (aPOR: $0.61,95 \% \mathrm{Cl}: 0.44$ to 0.85 ). Data represented in the figures are shown in the accompanying table.

\section{A) Unvaccinated COVID-19 cases}

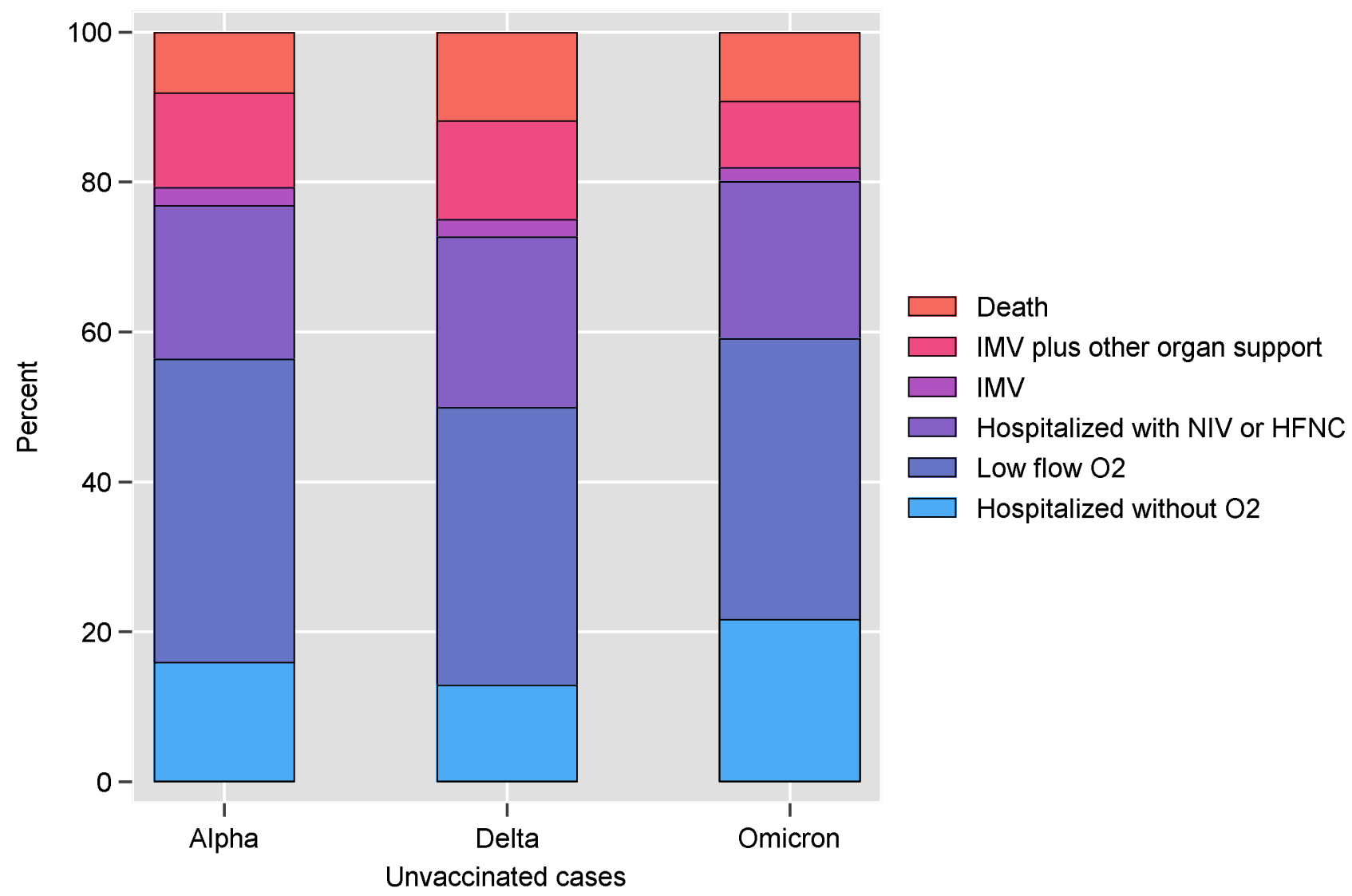


medRxiv preprint doi: https://doi.org/10.1101/2022.02.06.22270558; this version posted February 7, 2022. The copyright holder for this preprint (which was not certified by peer review) is the author/funder, who has granted medRxiv a license to display the preprint in perpetuity.

All rights reserved. No reuse allowed without permission.

\section{B) Vaccinated COVID-19 cases}

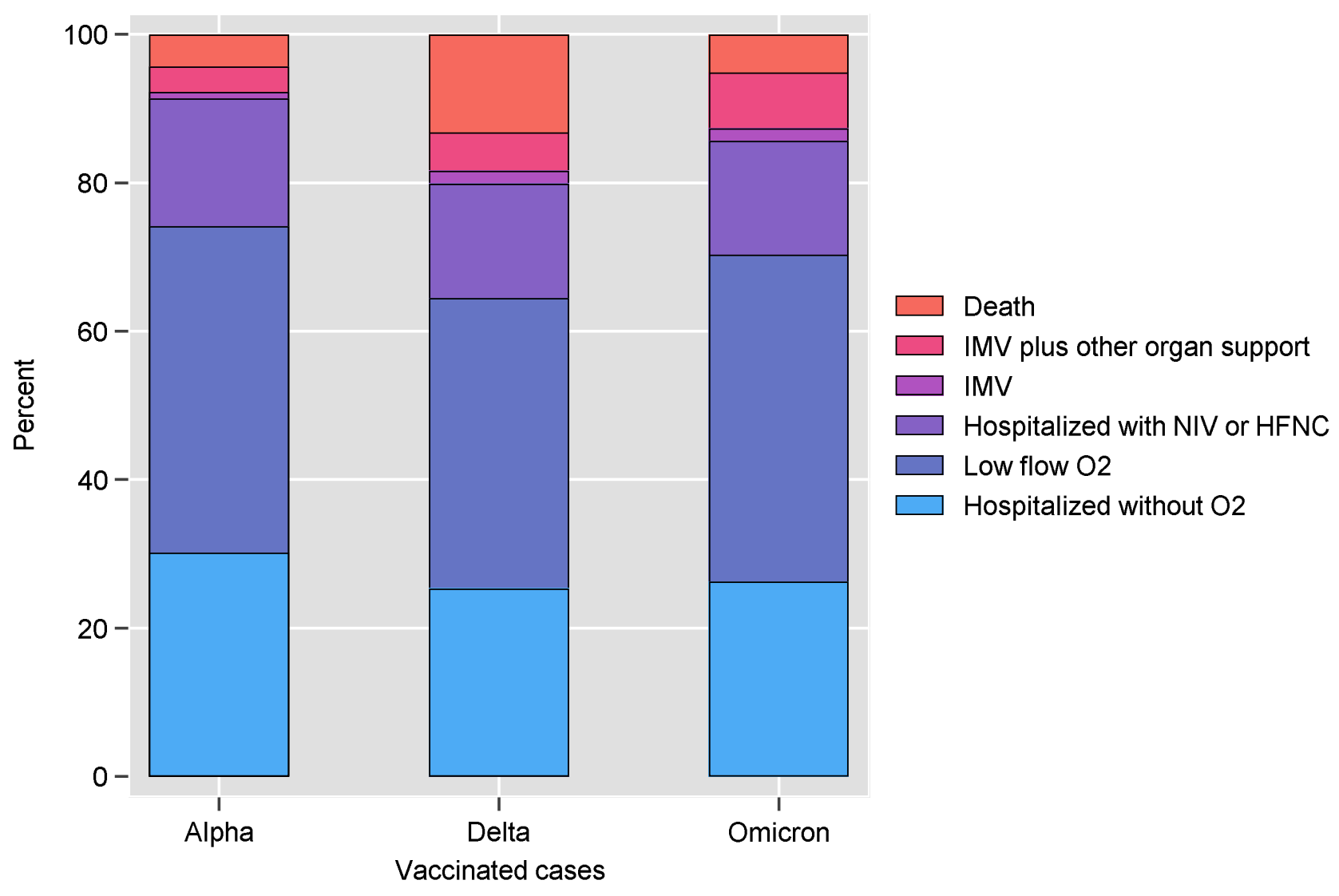


Figure 3 accompanying data table

\begin{tabular}{|c|c|c|c|c|c|c|}
\hline \multirow{2}{*}{$\begin{array}{l}\text { Severity } \\
\text { Category, no. } \\
\text { (\%) }\end{array}$} & \multicolumn{2}{|c|}{ Alpha } & \multicolumn{2}{|c|}{ Delta } & \multicolumn{2}{|c|}{ Omicron } \\
\hline & $\begin{array}{l}\text { Unvaccinated } \\
(n=944)\end{array}$ & $\begin{array}{c}\text { Vaccinated } \\
(n=116)\end{array}$ & $\begin{array}{l}\text { Unvaccinated } \\
(n=2743)\end{array}$ & $\begin{array}{c}\text { Vaccinated } \\
(n=1045)\end{array}$ & $\begin{array}{l}\text { Unvaccinated } \\
\quad(n=272)\end{array}$ & $\begin{array}{c}\text { Vaccinated } \\
(n=293)\end{array}$ \\
\hline $\begin{array}{l}\text { In-hospital } \\
\text { death }\end{array}$ & $76(8.1)$ & $5(4.3)$ & $323(11.8)$ & $138(13.2)$ & $25(9.2)$ & $15(5.1)$ \\
\hline $\begin{array}{l}\text { Hospitalized } \\
\text { with IMV plus } \\
\text { other organ } \\
\text { support }\end{array}$ & $119(12.6)$ & $4(3.4)$ & $360(13.1)$ & $54(5.2)$ & $24(8.8)$ & $22(7.5)$ \\
\hline $\begin{array}{l}\text { Hospitalized } \\
\text { with IMV }\end{array}$ & $23(2.4)$ & $1(0.9)$ & $65(2.4)$ & $18(1.7)$ & $5(1.8)$ & $5(1.7)$ \\
\hline $\begin{array}{l}\text { Hospitalized } \\
\text { with NIV or } \\
\text { HFNC }\end{array}$ & $193(20.4)$ & $20(17.2)$ & $624(22.7)$ & $161(15.4)$ & $57(21.0)$ & $45(15.4)$ \\
\hline $\begin{array}{l}\text { Hospitalized } \\
\text { with low flow } \\
\mathrm{O} 2\end{array}$ & $382(40.5)$ & $51(44.0)$ & $1017(37.1)$ & 409 (39.1) & $102(37.5)$ & $129(44.0)$ \\
\hline $\begin{array}{l}\text { Hospitalized } \\
\text { without } 02\end{array}$ & $151(16.0)$ & $35(30.2)$ & 354 (12.9) & $265(25.4)$ & $59(21.7)$ & $77(26.3)$ \\
\hline
\end{tabular}

Definitions: $\mathrm{HFNC}=$ high-flow nasal cannula; IMV = invasive mechanical ventilation; $\mathrm{O2}$ = oxygen; NIV = non-invasive ventilation 
Figure 4. Vaccine effectiveness of two or three doses of COVID-19 mRNA vaccines among adults hospitalized with COVID-19 to prevent disease progression to invasive mechanical ventilation or death, by SARS-CoV-2 variant.

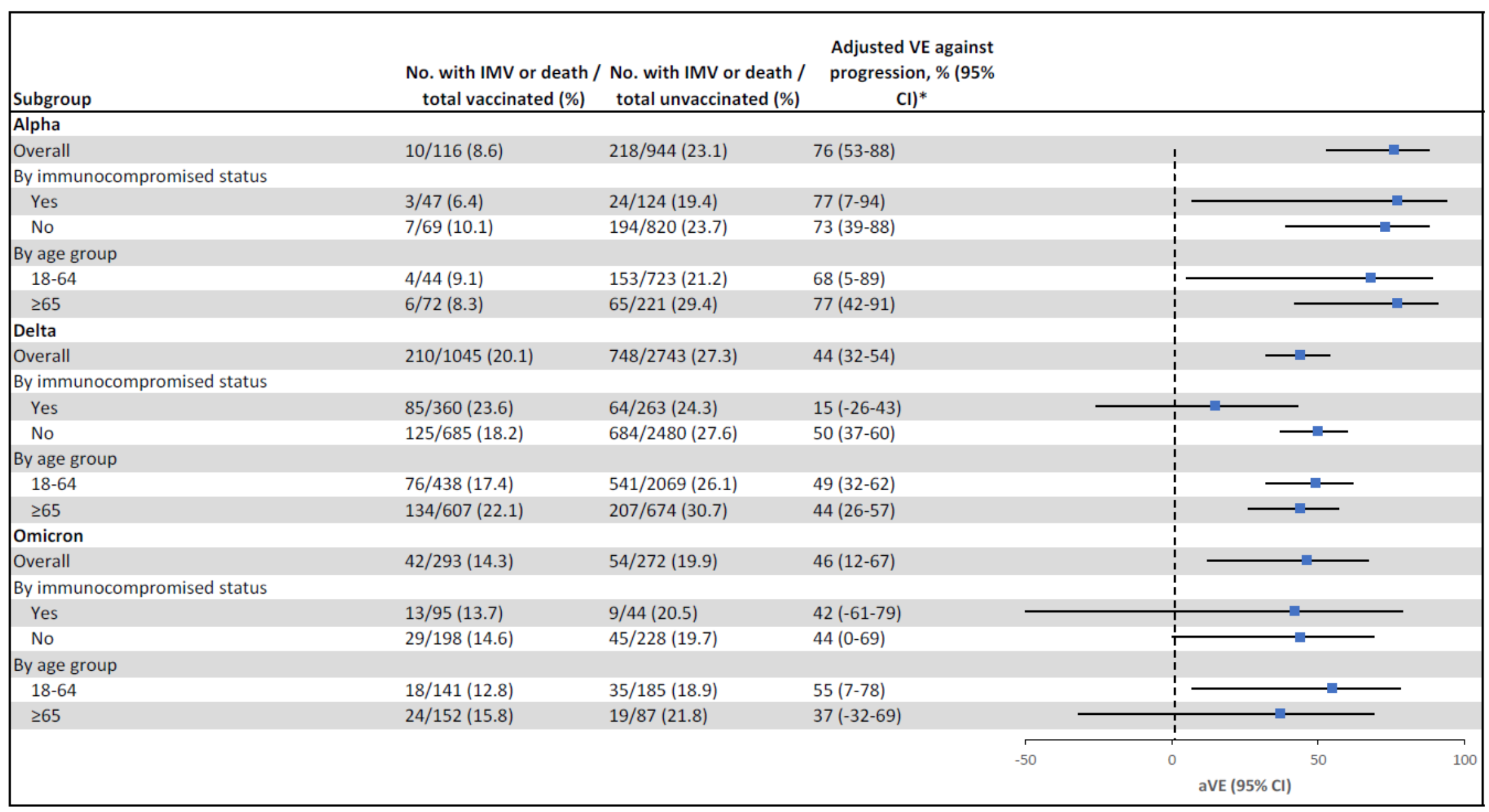

Definitions: IMV = invasive mechanical ventilation; VE = vaccine effectiveness 